Movement Disorder Surgery 


\section{Progress in Neurological Surgery}

\section{Vol. 15}




\section{Movement Disorder Surgery}

Volume Editor

A.M. Lozano, Toronto, Ont.

62 figures and 31 tables, 2000

KARGER $\begin{aligned} & \text { Basel·Freiburg } \cdot \text { Paris } \cdot \text { London } \cdot \text { New York } \\ & \text { New Delhi·Bangkok·Singapore } \cdot \text { Tokyo } \cdot \text { Sydney }\end{aligned}$ 


\section{(n) \\ Andres M. Lozano, MD, PhD, FRCS(C)}

Toronto Western Hospital Research Institute

Division of Neurosurgery

Department of Surgery

University of Toronto

Toronto, Ont., Canada

Library of Congress Cataloging-in-Publication Data

Movement disorder surgery / volume editor, A.M. Lozano.

p.; cm. - (Progress in neurological surgery; vol. 15)

Includes bibliographical references and indexes.

ISBN 3805569904 (hard cover : alk. paper)

1. Movement disorders - Surgery. 2. Brain - Surgery. I. Lozano, A.M. (Andres M.),

1959. II. Series.

[DNLM: 1. Movement Disorders - surgery. 2. Brain - surgery. WL 390 M9347 2000] RC376.5.M696 2000

$616.8^{\prime} 3-\mathrm{dc} 21$

00-037076

Bibliographic Indices. This publication is listed in bibliographic services, including Current Contents ${ }^{\circledR}$ and Index Medicus.

Drug Dosage. The authors and the publisher have exerted every effort to ensure that drug selection and dosage set forth in this text are in accord with current recommendations and practice at the time of publication. However, in view of ongoing research, changes in government regulations, and the constant flow of information relating to drug therapy and drug reactions, the reader is urged to check the package insert for each drug for any change in indications and dosage and for added warnings and precautions. This is particularly important when the recommended agent is a new and/or infrequently employed drug.

All rights reserved. No part of this publication may be translated into other languages, reproduced or utilized in any form or by any means electronic or mechanical, including photocopying, recording, microcopying, or by any information storage and retrieval system, without permission in writing from the publisher.

(C) Copyright 2000 by S. Karger AG, P.O. Box, $\mathrm{CH}-4009$ Basel (Switzerland)

www.karger.com

Printed in Switzerland on acid-free paper by Reinhardt Druck, Basel

ISSN 0079-6492

ISBN 3-8055-6990-4 


\section{Contents}

IX Preface

History

1 History of Movement Disorder Surgery

Gildenberg, P.L. (Houston, Tex.)

Anatomical and Physiologic Substrates

21 Anatomical Considerations in Basal Ganglia Surgery Parent, A.; Cossette, M.; Lévesque, M. (Beauport, Qué.)

31 Pathophysiological Considerations in Basal Ganglia Surgery: Role of the Basal Ganglia in Hypokinetic and Hyperkinetic Movement Disorders Wichmann, T.; DeLong, M.R.; Vitek, J.L. (Atlanta, Ga.)

58 Functional Models of the Basal Ganglia: Where Are We?

Obeso, J.A.; Guridi, J.; Rodriguez-Oroz, M.C. (Pamplona); Macias, R. (La Habana); Rodriguez, M. (La Laguna); Alvarez, L.; Lopez, G. (La Habana)

Patient and Technical Considerations

78 Movement Disorder Surgery: Patient Selection and Evaluation of Surgical Results

Tan, E.-K.; Jankovic, J. (Houston, Tex.)

91 Technical Considerations in Movement Disorder Surgery: Frames, Imaging and Intraoperative Monitoring

Thompson, T.P.; Lunsford, L.D.; Kondziolka, D. (Pittsburgh, Pa.) 
103 Microelectrode Recordings in Movement Disorder Surgery

Hutchison, W.D.; Lozano, A.M. (Toronto, Ont.)

Procedures and Techniques

118 Rational Basis for Pallidotomy in the Treatment of Parkinson's Disease Bakay, R.A.E.; Vitek, J.L. (Atlanta, Ga.)

132 Non-Microelectrode Recording-Guided Pallidotomy Bowen, J.; Munro-Davies, L.E. (Oxford); Silburn, P. (Brisbane); Gregory, R. (Oxford); Bain, P. (London); Scott, R.B.; Joint, C. (Oxford); Hall, B. (Brisbane); Stein, J. (Oxford); Aziz, T. (Oxford/London)

148 Stimulation of the Globus pallidus internus Gross, C.E. (Bordeaux)

156 Thalamotomy with Microelectrode Recordings Linhares, M.N.; Tasker, R.R. (Toronto, Ont.)

172 Thalamotomy without Microelectrode Recording Slavin, K.V.; Burchiel, K.J. (Portland, Oreg.)

181 Thalamic Deep Brain Stimulation for Tremor Wilkinson, S.B.; Koller, W.C. (Kansas City, Kans.)

188 Subthalamic Nucleus Lesions Gill, S.S.; Heywood, P. (Bristol)

196 Subthalamic Nucleus Deep Brain Stimulation Benabid, A.L.; Koudsie, A.; Benazzouz, A.; Piallat, B.; Van Blerkom, N.; Fraix, V.; Pollak, P. (Grenoble)

Controversies, Adverse Events, Emerging Insights and Indications

227 Movement Disorder Surgery: Lesions or Stimulation? Clatterbuck, R.E.; Lee, J.-I.; Lenz, F.A. (Baltimore, Md.)

236 What Does Stimulation in the Brain Actually Do? Ashby, P. (Toronto, Ont.)

246 Complications of Movement Disorder Surgery and How to Avoid Them Hariz, M.I. (Umeå)

266 Neuropsychological Considerations in Movement Disorder Surgery Saint-Cyr, J.A.; Trépanier, L.L. (Toronto, Ont.)

272 The Gamma Knife in Movement Disorder Surgery Young, R.F. (Los Angeles, Calif.)

279 Stereotactic Neurosurgery for Dystonia Yoshor, D.; Hamilton, W.J.; Desaloms, J.M.; Ondo, W.; Jankovic, J.; Grossman, R.G. (Houston, Tex.) 
296 Surgery for Spasmodic Torticollis

Villavicencio, A.T.; Friedman, A.H. (Durham, N.C.)

331 Neural Transplantation in Parkinson's Disease

Freeman, T.B.; Willing, A.E.; Zigova, T.; Sanberg, P.R.; Hauser, R.A. (Tampa, Fla.)

339 Neurosurgical Treatment of Spasticity

Sindou, M.; Mertens, P. (Lyon)

351 Functional Imaging of the Basal Ganglia

Nakamura, T.; Edwards, C.; Krch, D.; Mentis, M.; Eidelberg, D. (Manhasset, N.Y.)

371 CNS Drug Delivery for Movement Disorders

Penn, R.D.; Kroin, J.S. (Chicago, III.)

381 Gene Therapy Approaches to Parkinson's Disease

Freese, A. (Philadelphia, Pa.)

395 Author Index

396 Subject Index 


\section{. \\ Preface}

Never before has functional neurosurgery for movement disorders held such interest and prominence. The convergence of several paths including advances in the understanding of the cellular pathophysiology of motor dysfunction, the development of better brain imaging, refinements in neurophysiologic guidance and the emergence of new and improved implantable devices are setting the stage for novel therapeutic strategies and major advances in this field.

The field of movement disorders is now clearly multidisciplinary. Neurosurgeons have joined with neurologists, neuroanatomists, neurophysiologists, psychologists, neuroradiologists, neuroimaging scientists, molecular biologists and others. Each has brought their unique skills and expertise. We have formed strong partnerships. The flow of knowledge has occurred freely and at an intense pace and we are all further ahead for it.

The purpose of this volume is to provide an appraisal of the scientific basis and current and potential future usage of neurosurgery for movement disorders. The major clinical problems being treated surgically are covered in depth with, because of space considerations, lesser mention of the surgical management of less common disorders of motor function. An integrated multidisciplinary approach to the diagnosis, evaluation and treatment of patients with movement disorders is emphasized. This work covers the history of movement disorder surgery, its anatomical and physiologic basis and a discussion of which patients are candidates for these procedures. The technical tools and procedures at our disposal are discussed with an emphasis on providing alternate, sometimes even controversial surgical approaches. The operations in current usage are detailed stressing their indications, impact on the 
signs and symptoms and their adverse effects and when appropriate, their postulated mechanism of action. Throughout the volume, the scientific rationale for interventions and the insights and discoveries that are emerging related to performing this surgery are highlighted.

The contributors have been chosen on the basis of their expertise and important contributions to the field. It is acknowledged that multiauthored texts can often contain conflicting nonreconciled information. This approach has been adopted intentionally. This is a relatively young, rapidly evolving field with several varied approaches and ideas showing promise. It is best at this point to weave these various contributions into the multidimensional and dynamic fabric of the field of movement disorder surgery.

I am indebted to my colleagues Drs Anthony Lang, Jonathan Dostrovsky, Bill Hutchison, Ronald Tasker, Karen Davis, Peter Ashby, and Jean SaintCyr for their stimulating input, wise advice and ongoing collaboration. I acknowledge the help of my assistants Mary Anne Browne and Anne Chiacchieri. I would also like to thank the staff at Karger, especially Angela Weber and Rolf Steinebrunner, for their expert handling of this project.

Andres M. Lozano 